\title{
THE ACT OF REMEMBERING IN "OUT OF THE CRADLE ENDLESSLY ROCKING"
}

JANET S. ZeHR

Most EXPLICATORS of Whitman's "Out of the Cradle Endlessly Rocking" fit neatly - with just a little forcing-into three boxes. One box contains the biographical readers who see in the poem evidence of a crisis in Whitman's life: for many it is a thinly disguised song of mourning for a lost - to both Whitman and the critics-love. ${ }^{1}$ The second group makes the poem a more universal one in which Whitman resolves cosmic paradoxes. ${ }^{2}$ I place psychological critics, though I may be cramming rather too hard here, in this box: for them Whitman's longing is for, specifically, the "oceanic feeling" discussed by Freud, the inability to distinguish self from that we felt as babes at our mothers' breasts. This merging can occur again only in death. ${ }^{3}$ More lonely in a third box are those who feel the poem is about the process of writing poetry. Most notable in this group are Roy Harvey Pearce and Paul Fussell, Jr., who see Whitman as poet, not prophet, and stress the process of translation that allows a man to make symbols and metaphors. In Pearce's opinion, the adult poet looks back on "the potential for understanding" that he had as a child, finally realizing that potential in the act of making a poem. ${ }^{4}$

I very much like these suggestions that the poem is about the processes of the poet's mind. But I would democratize these readings somewhat and suggest that many of these same processes occur in the minds of all men and women. As Wordsworth suggests, the poet is thinking and expressing himself just as other people do, only better. In the readings of Pearce and Fussell are some implicit assumptions that I would like to make explicit. The poem is at least in part about memory and the way men's and women's minds, of which the poet's mind is the apotheosis, re-shape the events of the past. This re-shaping constantly alters time so that our conventional divisions of time - past, present, and future - are not quite adequate. In examining time in "Out of the Cradle," I can see a passage-way between the box in which I've placed Pearce and Fussell, stressing the workings of a poetic mind, and the one in which I've placed those who see Whitman as a prophet working with cosmic paradoxes and re-shaping our notions of the universe. As Whitman goes through the ordinary human act of remembering, he breaks down time barriers, showing us how we all are "uniter[s] of here and hereafter." 5

John F. Lynen, whose perceptive work with Whitman's poetry is much 
too large in scope to fit into any of my convenient boxes, deals with memory and time in Whitman's poetry as he points out the tension between Whitman's tendency not only to record with precision the details of nature and human life but also to spout the generalities of a seer. As he turns specifically to time, Lynen notes Whitman's similar attempts to reconcile the "all times of the seer with the right-now of the earth bound individual." 6 In general, says Lynen, "Whitman's poetry is, above all, a poetry of the now, a poetry which not only depicts the present moment but makes the poem itself exist as that moment and portrays all events, objects, and thoughts as things now appearing to consciousness."7 In "Out of the Cradle," Lynen notes ways that Whitman plays with time. There are "eight different levels of time" in the poem. ${ }^{8}$ Devices that merge these levels of time are the poet's addresses to the audience, when the present participles and other tricks with tenses that give the illusion of a timeless present. ${ }^{9}$

Examining more specifically the workings of memory in "Out of ithe Cradle" reveals more ways in which various levels of time are blended. Whitman initially encouraged the idea that the poem was about the process of memory by entitling the poem "A Child's Reminiscence." Although a woman who heard the poem read by Whitman said the events were, as far as she knew, based on real experiences, we certainly will never know. ${ }^{10}$ Whitman surely asks of us, however, that we accept the fictional situation which involves a man looking back on childhood events.

In the poem, Whitman begins playing with time immediately. The rhythms of the long initial sentence-"Out of the," "Down from the," "Up from the"-create new poetic rhythms, new patterns in time. As Lynen says, the present participles of the same sentence- "rocking," "twining and twisting," "twittering," "revisiting" (pp. 246-247)-create an endless present that need not be linked to any specific moment. The adult poet states that he is undergoing a transformation in time: "A man, yet by these tears a little boy again" (p. 247) and that he has the ability to unite "here and hereafter" (p. 247). In the next stanza, he begins "Once Paumanok," but, without any verb to indicate what happened "once," goes on to describe what happened not "once" but "every day" (pp. 247-248).

This "once" clearly works as a story-telling convention and may not be as illogical as it first appears. It illustrates, however, the most striking type of time dislocation in the poem. The process of remembering and the tricks with time it involves are most obvious in the confusion between events that were repeated and those that occurred only once. This is the same confusion noted by Gèrard Genette in another exposition of memory, $A$ la Recherche $d u$ Temps Perdu. Whitman, like Proust, states that events occurred over and over again, but then recalls them using particular details that could only have marked one event. ${ }^{11}$ The first example involves the bird's naive and happy 
love song. Whitman says this song was sung and/or interpreted by the boy over and over again: "And every day I, a curious boy, never too close, never disturbing them, / Cautiously peering, absorbing, translating" (p. 248; italics added). The song proceeds, however, word for word:

\author{
Shine! shine! shine! \\ Pour down your warmth, great sun! \\ While we bask, we two together. (p. 248)
}

This seemingly spontaneous bird song could not have been sung in precisely the same way every day. Nor would the boy have understood or translated the song in precisely this way every day. The man remembers one particular time that best represents what happened in more or less the same way every day. Or, perhaps more accurately, the man/poet in the present constructs one moment, a composite moment that may have very little relation to what actually occurred, that can relay the emotions of many more or less similar moments in the past. The poem seems to represent the process of remembering, quite apart from the process of making a poem from a memory, very accurately. We as ordinary human beings can think only of a representative "one time" or construct a composite memory of a time that never really existed at all.

This process is even more evident in the incident surrounding the bird's "carol of death." After Whitman relates an incident that clearly occurred only once ("One forenoon the she-bird crouch'd not on the nest"), he continues to tell about repeated incidents: "thenceforward all summer . . . I saw, I heard . . . the he-bird" (p. 248). A short specific song ("blow my mate to me") again casts doubt on the repetitive nature of these experiences, as does, to a certain extent, the specific picture of the bird sitting "Ont the prong of a moss-scallop'd stake" and of the boy weeping and crawling through the shadows (pp. 248-249). Again the specific details of one time, real or fictional, begin to stand for every time. The third and longest song, more than any of the other songs, carries us to a specific time. The song begins with pathetic hope in the face of all the indications that the mate is dead: "O night! do I not see my love fluttering out among the breakers? / What is that little black thing I see there in the white?"(p. 249). It ends in despair with the acceptance of the fact that the mate is indeed dead: "But my mate no more, no more with $m e ! / W e$ two together no more" (p. 251). The realization at the end of the song is a final one and a significant alteration of the bird's hope at the beginning. The bird would not go through this disturbing progression toward understanding more than once. Clearly we have moved out of repeating time with no overt signals from Whitman.

After the song, the boy's experience is introduced as a repeated one: "For more than once dimly down to the beach gliding . . . I . . . Listen'd long and 
long" (p. 249; italics added). But the epiphany that follows is, like the bird's realization, clearly one experience. Like the bird, he learns something that cannot be un-learned: at first, he does not understand the word from the waves; then, of course, he does. In attempting to remember every time, the adult poet is swept into another time by the process of remembering as his composite memory becomes vivid and particular, clearly becoming one time rather than every time.

A similar and, I think, related blending of times occurs with the speaking roles of the poem, those of the adult poet, the boy, and the bird. The "translated" songs cannot clearly be attributed to bird, boy, or man. Certainly, the bird is anthropomorphized by the boy or man and can hardly be said to speak. Whitman suggests that the second speaker, the boy, can understand or translate a simple song of love and naive happiness: ". . . I, a curious boy, never too close, never disturbing them, / Cautiously peering, absorbing, translating" (p. 248). The "death's carol," however, requires the mature mind of the poet to translate it. "Translating" becomes "now translating" before the long song occurs in the poem, suggesting that only now does the poet understand what he heard as a boy. Roy Harvey Pearce's perception about the child's potential for understanding seems clear here. The confusion about who is singing this translation is a confusion in time: was the song heard by the boy in the past or translated only by the adult poet in the poem's present? Later, the poet says, the bird "pour'd forth those meanings which I of all men know" (p. 249). The boy may not have known those meanings because the poet says that this knowledge is with him only now that he is a man.

St. Augustine postulates that instead of past, present, and future, the only times are "the present of things past," "the present of things present," and "the present of things future." 12 Whitman is a master of the present and seems to prove St. Augustine's theory by re-shaping the past. As Whitman "translates" or "takes all hints and leaps beyond them" he creates times that never quite existed before as a new understanding alters past events as they took place before. Perhaps even more clearly the process of creating a composite or totally fictional event to objectify repeated past events creates this "present of things past": this past very literally did not exist before the present.

Certainly this poem is immense in scope. I would not want to imply that its only subject is memory. But the poem does demonstrate that the uniting of here and hereafter in memory is a sort of mystical experience available to us all that can break down our mental barriers. The poem celebrates the imagination, both of the poet and of every man and woman, and the new kinds of reality it can build.

\section{University of Illinois at Urbana-Champaign}




\section{NOTES}

1 These critics include Gay Wilson Allen in The Solitary Singer: A Critical Biography of Walt Whitman (New York: New York University Press, 1967), Frederik Schyberg in Walt Whitman, trans. Evie Allison Allen (New York: Columbia University Press, 1951), and Stephen E. Whicher in "Whitman's Awakening to Death-Toward a Biographical Readingof 'Out of the Cradle Endlessly Rocking'" in A Century of Whitman Criticism, ed. Edwin Haviland Miller (Bloomington, Indiana: Indiana University Press, 1969), pp. 285-292.

2 These critics include Tracey R. Miller in "The Boy, the Bird, and the Sea: An Archetypal Reading of 'Out of the Cradle,'" Walt Whitman Review 19 (1973), pp. 93-103; James E. Miller, Jr., Karl Shapiro, and Bernice Slote, in Start with the Sun (Lincoln: University of Nebraska Press, 1960), pp. 184-185.

3 Sigmund Freud, Civilization and its Discontents (New York: Norton, 1962), p. 11. Gustav Bychowski offers a psychological reading in "Walt Whitman-A Study in Sublimation" in $A$ Century of Whitman Criticism, pp. 203-215.

4 Roy Harvey Pearce, "Whitman Justified: The Poet in 1860," pp. 72-109 and Paul Fussell, Jr., "Whitman's Curious Warble: Reminiscence and Reconciliation," pp. 28-51 in R. W. B. Lewis, The Presence of Walt Whitman: Selected Papers from the English Institute (New York: Columbia University Press, 1962). Fussell's essay also suggests that through these poetic processes the boy can resolve some "transcendental paradoxes" (p. 43).

5 Walt Whitman, Leaves of Grass: Comprehensive Readers Edition, ed. Harold W. Blodgett and Sculley Bradley (New York: New York University Press, 1965), p. 247. Further references to this work will be given parenthetically in the text.

6 John F. Lynen, The Design of the Present: Essays on Time and Form in American Literature (New Haven: Yale, 1969), p. 328. Other critics who deal with time in Whitman's poetry include James E. Miller, Jr., in A Critical Guide to Leaves of Grass (Chicago: University of Chicago Press, 1957), p. 123; Steven Kagle in "Time as a Dimension in Whitman," American Transcendental Quarterly 12 (1971), pp. 55-60; and Gay Wilson Allen, pp. 142, 162.

7 Lynen, p. 279.

8 Lynen, p. 323.

9 Lynen, pp. 323-325.

10 R. M. Bucke, Walt Whitman (Philadelphia, 1883), p. 29, in Walt Whitman's Poems, p. 165.

11 Gèrard Genette, "Time and Narrative in Àla Recherche du Temps Perdu," trans. Paul de Man in Aspects of Narrative, ed. J. Hillis Miller (New York: Columbia University Press, 1971), pp. 94-118.

12 St. Augustine, Confessions, [XI], trans. Edward B. Pusey (New York: Random House, (1949), p. 258. 